\title{
Radioimmunologic Measurements of Naturally Occurring Antibodies. III. Antibodies Reactive with Escherichia coli or Bacteroides fragilis in Breast Fluids and Sera of Mothers and Newborn Infants
}

\author{
MICHELINE T. STE-MARIE, (3 3) EVELYN M. LEE, AND WILLIAM R. BROWN
}

Division of Gastroenterology and Department of Medicine, University of Colorado Medical Center and Denver Veterans Administration Hospital; and Newborn Center, Children's Hospital, Denver, Colorado, USA

\section{Extract}

Immunoglobulin (Ig) A antibodies to Bacteroides fragilis and Escherichia coli in breast fluids and serum of lactating women, and IgG antibodies to $E$. coli in cord and maternal sera of mother-infant pairs were measured by a radioimmunoassay. Antibody concentrations were expressed as micrograms of antibody per milliliter or per milligram of $\operatorname{IgA}$ or IgG. For concentrations (mean \pm SD) of IgA antibodies, see Table 1 .

Concentrations of secretory IgA in breast fluids were $36.7 \pm$ $25.3 \mathrm{mg} / \mathrm{ml}$ on day $1,1.66 \pm \mathrm{mg} / \mathrm{ml}$ on day 4 , and $0.71 \pm 0.31$ $\mathrm{mg} / \mathrm{ml} 6$ weeks after delivery. Both the amount of $\operatorname{IgA}$ antibodies $(\mu \mathrm{g} / \mathrm{ml})$ and total $\operatorname{IgA}$ in colostrum fell abruptly and reached serum levels by the 4 th postpartum day. The 23-30-fold greater quantity of IgA antibodies per milliliter for day 1 colostrum than IgA antibodies per milliliter of serum at delivery corresponded to a 21 -fold higher total concentration of IgA in colostrum than in serum at these times. Concentrations of antibodies to $B$. fragilis and $E$. coli were not significantly different.

Concentrations of IgG antibodies to $E$. coli in 10 maternal sera at delivery $(2.1 \pm 1.6 \mu \mathrm{g} / \mathrm{ml} ; 0.33 \pm 0.29 \mu \mathrm{g} / \mathrm{mg} \mathrm{IgG})$ were slightly but not significantly lower than those in corresponding cord sera $(2.5 \pm 2.0 \mu \mathrm{g} / \mathrm{ml} ; 0.29 \pm 0.22 \mu \mathrm{g} / \mathrm{mg}$ IgG $)$. Concentrations of serum IgA anti-E. coli antibodies were similar in nursing and non-nursing mothers both at delivery and 6 weeks later, and these concentrations were similar to those in nonpregnant women.

Findings of the study indicate that $(1)$ the large quantities of IgA antibodies to $E$. coli and $B$. fragilis in colostrum result from the presence of large quantities of IgA rather than from $\operatorname{Ig} \mathrm{A}$ that is richer than serum $\operatorname{IgA}$ in specific antibodies; (2) concentrations of IgA antibodies to $E$. coli and $B$. fragilis in maternal serum and colostrum are similar, even though Bacteroides greatly outnumber coliforms in gut contents of adults; (3) concentrations of IgG antibodies to $E$. coli are similar in maternal and fetal circulation; (4) nursing and pregnancy do not influence concentrations of serum IgG antibodies to the bacteria studies.

\section{Speculation}

During lactation, the breast synthesizes $\operatorname{IgA}$ with constant levels of specific antibodies to commensal intestinal bacteria.
Ingested breast fluid antibodies to $B$. fragilis could suppress growth of Bacteroides in the gut and account for the relatively low numbers of these anaerobes in intestinal content of breast-fed infants.

The human breast secretes antibodies to some intestinal microorganisms $(1,9,14,19,20)$. The antibodies may help to protect breast-fed infants from enteric infections $(12,18)$, and determine the composition of the indigenous gut microflora $(20,24)$. Although such antibodies have been recognized for years, details concerning their biologic activities and the mechanisms by which they are synthesized and secreted are incompletely understood. This is due partly to limitations in methods used in their study. With the exception of some immunofluorescence studies (6), the antibodies have been evaluated only by complex antigen-antibody reactions such as agglutination or bactericidal activity $(1,9,14,19)$. None of these methods has measured the antibodies quantitatively, and often the immunoglobulin classes to which the antibodies belong have not been defined. It is well established, however, that the breast participates in the immunologic system of external secreting organs in which the principal immunoglobulin is $11 \mathrm{~S}$ exocrine $\operatorname{IgA}(2,4,25)$.

This laboratory recently developed radioimmunologic methods, based upon the primary binding of antibodies to bacteria, for quantitative measurement of naturally occurring antibodies in serum according to their immunoglobulin classes (3). In this study, we applied these methods to measurement of antibodies to $E$. coli or $B$. fragilis in maternal serum and breast secretions, and antibodies to $E$. coli in the cord serum and maternal serum of mother-infant pairs.

\section{METHODS}

SUBJECTS

Mothers were patients at Fitzsimons General Hospital who gave informed consent for the study. Seventeen ( 7 primiparous and 10 multiparous) mothers breast-fed their babies; 31 (18 primiparous and 13 multiparous) did not. Mean age in each group was 23 years. None of the mothers had recognized medical complications or infections during pregnancy or delivery. The infants, whose birth weights were appropriate for 
Table 1. Antibody concentrations

\begin{tabular}{|c|c|c|c|c|c|}
\hline \multirow[b]{2}{*}{ Antibodies to } & \multirow{2}{*}{$\begin{array}{c}\text { Time after } \\
\text { delivery }\end{array}$} & \multicolumn{2}{|c|}{ Breast fluids } & \multicolumn{2}{|c|}{ Serum } \\
\hline & & $\mu \mathrm{g} / \mathrm{ml}$ & $\mathrm{IgA}, \mu \mathrm{g} / \mathrm{mg}$ & $\mu \mathrm{g} / \mathrm{ml}$ & $\mathrm{IgA}, \mu \mathrm{g} / \mathrm{mg}$ \\
\hline \multirow[t]{3}{*}{ Escherichia coli } & day 1 & $14.8 \pm 13.9$ & $0.51 \pm 0.43$ & $0.64 \pm 0.31$ & $0.57 \pm 0.63$ \\
\hline & day 4 & $0.68 \pm 0.62$ & $0.41 \pm 0.34$ & & \\
\hline & $6 \mathrm{wk}$ & $0.33 \pm 0.22$ & $0.49 \pm 0.27$ & $0.57 \pm 0.22$ & $0.51 \pm 0.63$ \\
\hline \multirow[t]{2}{*}{ Bacteroides fragilis } & day 1 & $18.9 \pm 15.1$ & $0.63 \pm 0.68$ & $0.58 \pm 0.32$ & $0.49 \pm 0.44$ \\
\hline & day 4 & $0.73 \pm 0.30$ & $0.54 \pm 0.19$ & & \\
\hline
\end{tabular}

their gestational ages of $38-42$ weeks, were free of congenital malformations and infections.

\section{BREAST FLUIDS AND SERA}

Venous blood was drawn from mothers just before delivery and 6 weeks after delivery. Colostrum and breast milk were collected by manual expression during the first $24 \mathrm{hr}$ (day 1) and at 4 days and 6 weeks after delivery. Blood was allowed to clot for $12 \mathrm{hr}$ at $4^{\circ}$, and the serum was collected after centrifugation. Colostrum and milk were centrifuged $(7,000$ $\mathrm{rpm}$ for $60 \mathrm{~min}$ at $4^{\circ}$ ), and a layer intermediate between fat and the pellet was saved. The specimens were stored at $-20^{\circ}$ for 1 week to 6 months before study.

\section{BACTERIA}

Bacteria were the same strains used in a previous study from this laboratory (3). A nonpathogenic strain of $E$. coli (ATCC no. 11775) was obtained from the American Type Culture Collection (ATCC), Rockville, Md. An ATCC strain was selected because of its availability for repeated study. Because of the rough nature of the $E$. coli, it could not be typed by the usual methods used in this laboratory. $B$. fragilis was isolated from a septicemic patient's blood. The bacteria were cultured (in an anaerobic atmosphere for $B$. fragilis) in Bacto brain-heart infusion broth (27), washed in physiologic saline, and stored in $1 \%$ formalinized saline.

\section{ANTIBODY AND IMMUNOGLOBULIN PREPARATIONS}

Exocrine $11 \mathrm{~S} \mathrm{IgA}$ was purified from colostrum by DEAEcellulose (28) ion exchange chromatography and filtration (22) through Sephadex G-200 (29). Traces of IgM were removed from the $11 \mathrm{~S}$ IgA fraction by affinity column chromatography using Sepharose 4B (29) coupled to rabbit antihuman IgM (26). The final IgA preparation was pure as determined by immunoelectrophoresis and double immunodiffusion against a rabbit antiserum to whole human colostrum.

Rabbit anti-IgG globulin (7 S) was prepared as described previously (3) from rabbits that had been hyperimmunized with normal human serum IgG. Anti-IgA globulin was prepared by hyperimmunization of rabbits with human colostral $11 \mathrm{~S}$ IgA, absorption of the antiserum with human IgG, and precipitation of $\gamma$-globulins by ammonium sulfate at $33 \%$ saturation (22). The preparation then was specifically purified by affinity chromatography with Sepharose 4B coupled to human serum IgA. Antibodies eluted with $3 \mathrm{M}$ NaSCN (7) were monospecific for $\alpha$ chains of human IgA when tested by immunoelectrophoresis and double diffusion in agar gel against colostrum and serum. Specific antibodies, estimated by quantitative precipitation, comprised $60 \%$ of the total protein of the purified anti-IgA.

\section{IMMUNOGLOBULIN MEASUREMENTS}

Immunoglobulins in serum and breast fluids were measured by radial immunodiffusion in antibody-containing agar (16).
Reference standards for serum IgG and IgA measurements were $\operatorname{IgG}$ and monomeric IgA prepared from normal human serum (3). For measurement of IgA in breast fluids, $11 \mathrm{~S}$ colostral IgA was the reference standard.

\section{ANTIBODY MEASUREMENTS}

E. coli antibody concentrations were measured in all subjects and $B$. fragilis antibody concentrations were measured in 10 randomly selected mothers who were breast-feeding.

After absorption with $E$. coli and $B$. fragilis, the anti-IgG and anti-IgA globulins were labeled with ${ }^{125} \mathrm{I}(30)$ according to the chloramine- $\mathrm{T}$ method $(13) ; 1 \mathrm{mCi} \mathrm{Na}{ }^{125} \mathrm{I}$ was used to label $1 \mathrm{mg}$ protein.

The radioimmunoassay has been described in detail (3). Briefly, serum or colostrum was diluted in $0.01 \mathrm{M}$ phosphatebuffered saline (PBS) containing $0.0075 \mathrm{M}$ trisodium ethylenediaminetetraacetate (EDTA), $\mathrm{pH} 7.4$, to give an IgA concentration of about $0.5 \mathrm{mg} / \mathrm{ml}$ serum or $0.05 \mathrm{mg} / \mathrm{ml}$ colostrum. The fluids were incubated ( $4^{\circ}$ for $60 \mathrm{~min}$ ) with a suspension of either $E$. coli or $B$. fragilis (about $6 \times 10^{8}$ organisms). The bacteria were washed, resuspended in PBS-EDTA, and incubated $\left(4^{\circ}\right.$ for $60 \mathrm{~min}$ ) with radioiodinated anti-IgG or anti-IgA (400 ng antibody nitrogen in $0.5 \mathrm{ml}$ PBS-EDTA). After further washing, radioactivity in the bacterial suspensions was counted in an automatic $\gamma$-counter. A control aliquot of each fluid was handled identically except that it had been preabsorbed with the same species of bacteria that was added to experimental samples. Radioactivity of bacteria that had been incubated in control sera was subtracted from that of bacteria incubated in experimental sera, and the net amount of anti-IgG or anti-IgA bound to bacteria was determined by comparison to a known amount of labeled antibody.

From the amount of anti-IgG or anti-IgA specifically bound to the bacteria, the amount of $\operatorname{IgG}$ or $\operatorname{IgA}$ antibacterial antibody bound was estimated according to the relation between the anti-IgG or anti-IgA and purified serum $\operatorname{IgG}$, serum monomeric IgA, or $11 \mathrm{~S}$ colostral IgA in quantitative precipitin tests at equivalence. The ratio (milligram per milligram) of anti-IgA to $11 \mathrm{~S}$ colostral IgA was 2.9 and to serum IgA 2.4; the anti-IgG to IgG ratio was 2.2.

After radioactivity was counted, turbidity of the bacterial suspensions was measured spectrophotometrically at $620 \mathrm{~nm}$.

\section{RESULTS}

\section{SERUM AND BREAST FLUID IMMUNOGLOBULIN CONCENTRATIONS}

The concentration of IgG in 10 specimens of cord blood was $8.1 \pm 1.3(\mathrm{SD}) \mathrm{mg} / \mathrm{ml}$; in corresponding maternal sera it was $6.6 \pm 1.9 \mathrm{mg} / \mathrm{ml}$. The concentration of $\operatorname{IgA}$ at the time of delivery in sera of mothers who breast-fed their babies was $1.63 \pm 0.86 \mathrm{mg} / \mathrm{ml}$ (Fig. 1); in those who did not, it was $1.79 \pm$ $1.32 \mathrm{mg} / \mathrm{ml}$. These differences are not statistically significant. In colostrum or breast milk, the IgA concentration was $36.7 \pm$ $25.33 \mathrm{mg} / \mathrm{ml}$ at day $1,1.66 \pm 1.06 \mathrm{mg} / \mathrm{ml} 4$ days after delivery, and $0.71 \pm 0.31 \mathrm{mg} / \mathrm{ml} 6$ weeks after delivery (Fig. 1). 


\section{SPECIFICITY OF RADIOIMMUNOASSAY}

As in the previous study (3), specificity of the reactions between radiolabeled anti-human immunoglobulins and immunoglobulins bound to bacteria was confirmed in the assay by blocking the reactions with a 10 -fold excess of unlabeled antibody. Unlabeled anti-IgA completely blocked the specific binding of labeled anti-IgA to serum- or colostrum-treated bacteria, whereas anti-IgG and anti-IgM had no effect; similar specificity was demonstrated for the anti-IgG-IgG system when excess. anti-IgA or anti-IgM was added. Specificity of the reactions between bacteria and breast secretions or serum was tested by measuring the antibody content of the fluids after absorption with bacteria. B. fragilis removed less than $8 \%$ of $E$. coli antibody activity, $E$. coli removed less than $5 \%$ of $B$. fragilis antibody activity, and a single absorption with $B$.

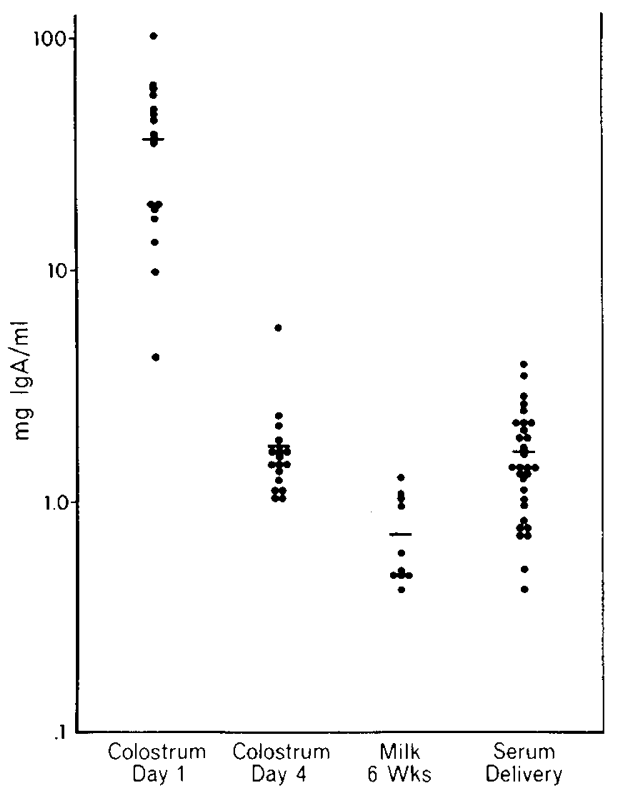

Fig. 1. Concentrations of immunoglobulin A $(\operatorname{IgA})$ in serum of lactating mothers at the time of delivery, in their colostrum during the first $24 \mathrm{hr}$ (day 1) and 4 days after delivery, and in their milk 6 weeks postpartum. Horizontal bars: mean values. fragilis and $E$. coli completely removed binding of $\operatorname{IgA}$ to these bacteria. The spectrophotometric density of control and experimental specimens never differed by more than $10 \%$, thus excluding the possibility that excessive loss of bacteria from the experimental samples had occurred.

\section{ANTIBODY CONCENTRATIONS}

Concentrations of antibacterial antibodies in sera or breast fluids were expressed as micrograms of antibody per milliliter of fluid or micrograms of antibody per milligram of either IgA or IgG. In breast fluids, concentrations of $\operatorname{IgA}$ antibodies reactive with $E$. coli were $14.8 \pm 13.9 \mu \mathrm{g} / \mathrm{ml}$ during day $1,0.68$ $\pm 0.62 \mu \mathrm{g} / \mathrm{ml}$ on day 4 , and $0.33 \pm 0.22 \mu \mathrm{g} / \mathrm{ml} 6$ weeks after delivery (Fig. $2 a$ ). In contrast to this abrupt decline in total amount of IgA antibody per milliliter of breast fluids during the 6-week period, the concentrations of specific antibody per milligram of $\mathrm{IgA}$ in day 1 colostrum $(0.51 \pm 0.43)$, day 4 colostrum $(0.41 \pm 0.34)$, and milk at 6 weeks $(0.49 \pm 0.27)$ were virtually constant (Fig. $2 b$ ). Maternal serum IgA antibody concentrations, expressed as micrograms of antibody per milliliter at the time of delivery $(0.64 \pm 0.31)$ were about 0.05 those in colostrum on day 1 , but 6 weeks later the concentrations in serum $(0.57 \pm 0.24)$ and breast milk $(0.33 \pm$ 0.22) were similar. By contrast, the amount of $\operatorname{IgA}$ antibody per milligram of IgA in serum both at delivery $(0.57 \pm 0.63$ $\mu \mathrm{g} / \mathrm{mg})$ and 6 weeks after delivery $(0.51 \pm 0.63 \mu \mathrm{g} / \mathrm{mg})$ was similar to those in breast fluids.

The concentrations of IgA antibodies reactive with $B$. fragilis in maternal serum at delivery and in day 4 colostrum did not differ significantly from the IgA anti-E. coli concentrations in these fluids (Fig. 3 ).

Concentrations of $\operatorname{IgA}$ antibodies in breast fluids and serum of individual mothers were not correlated.

The concentrations of IgG antibodies reactive with $E$. coli in 10 maternal sera at delivery were similar to those in the corresponding cord sera (Fig. 4).

No differences were found in the concentrations of IgA anti- $E$. coli antibodies in sera of nursing and non-nursing mothers either at delivery or 6 weeks later. In both groups, concentrations declined slightly but insignificantly during the 6 -week period. Concentrations were similar to those in a group of nonpregnant, nonlactating females (3).

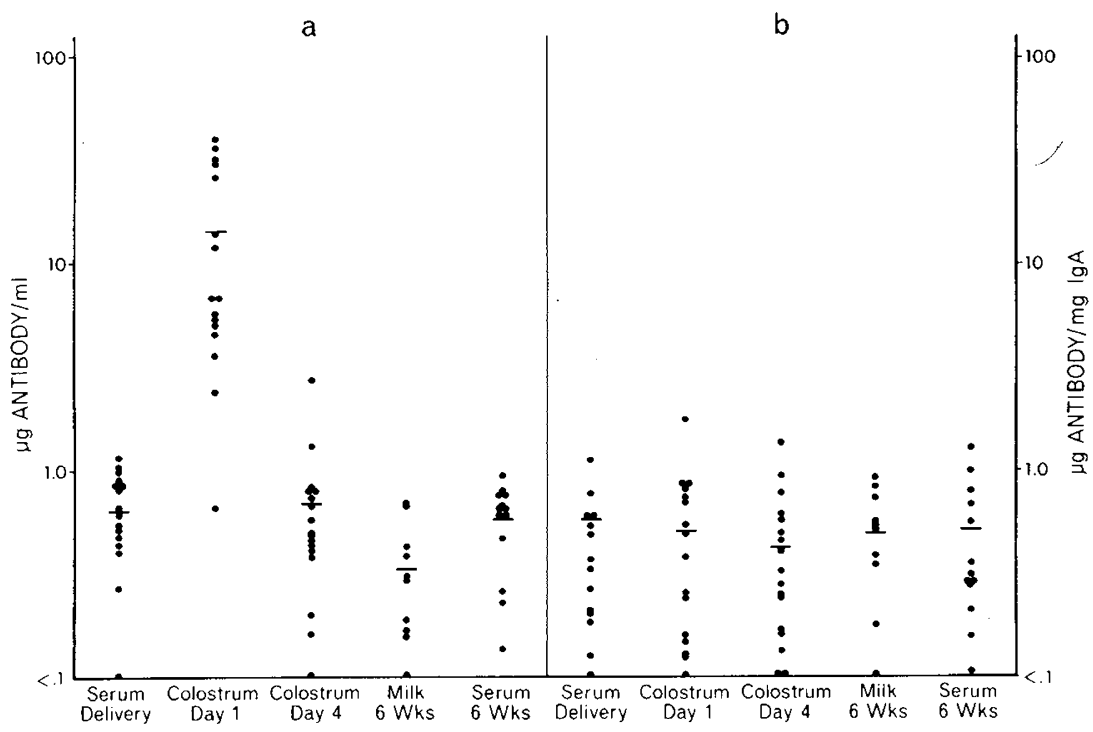

Fig. 2. Immunoglobulin A $(\operatorname{IgA})$ anti-Escherichia coli antibodies in serum of lactating mothers at delivery and 6 weeks later, and in breast fluids at day 1 , day 4 , and 6 weeks after delivery. $a$ : antibody concentration expressed as micrograms of antibody per milliliter of serum or colostrum. $b$ : antibody concentration expressed as micrograms of antibody per milligram of $\operatorname{IgA}$. 


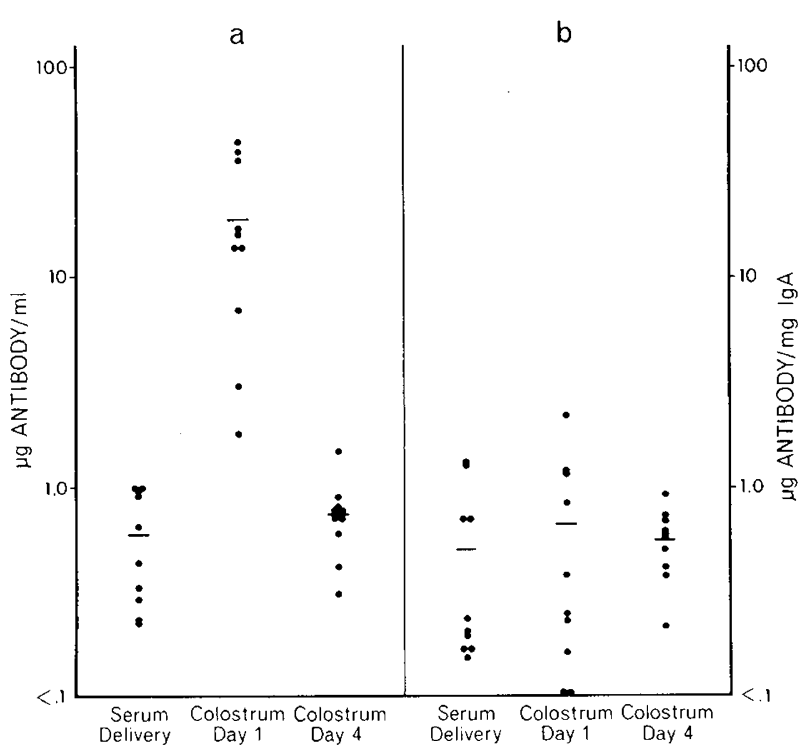

Fig. 3. Immunoglobulin A (IgA) anti-Bacteroides fragilis antibodies in serum and breast fluids of lactating mothers. $a$ : antibody concentration expressed as micrograms of antibody per milliliter of fluid. $b$ : antibody concentration expressed as micrograms of antibody per milligram of $\lg \mathrm{A}$.

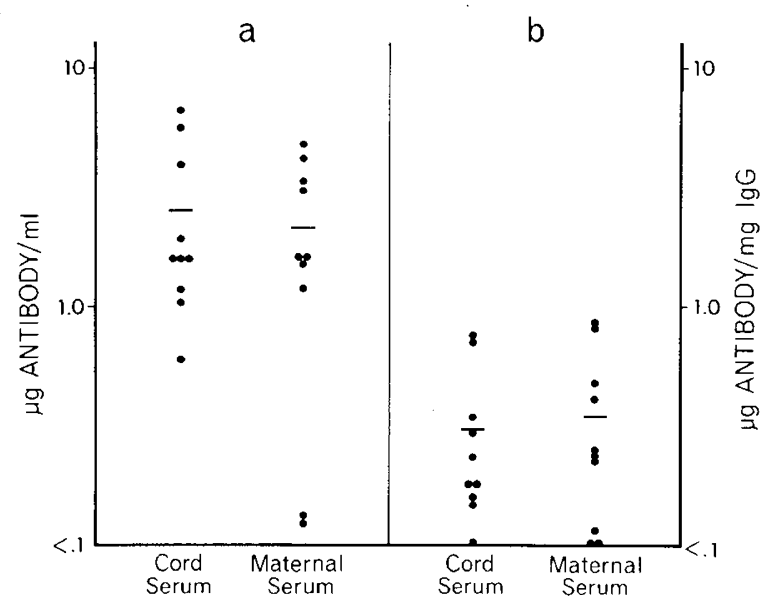

Fig. 4. Immunoglobulin $\mathrm{G}(\mathrm{Ig} G)$ anti-Escherichia coli antibodies in 10 paired cord and maternal sera at the time of delivery. $a$ : antibody concentration expressed as micrograms of antibody per milliliter of serum. $b$ : antibody concentration expressed as micrograms of antibody per milligram of IgG.

\section{DISCUSSION}

This study has demonstrated by quantitative methods that the human breast secretes $\mathrm{IgA}$ antibodies to $E$. coli and $B$. fragilis, two genera of bacteria that are indigenous to the human gastrointestinal tract. In order to reproduce as closely as possible the in vivo reaction of antibodies with bacteria in the intestinal tract, whole bacteria were used in this study. Since minimal cross-reactivity between antibodies to $E$. coli and $B$. fragilis was demonstrated, it is assumed that bacterial antigens detected were specific for the species.

The amount of antibodies present in colostrum (micrograms of antibody per milliliter) during the first day of lactation is higher (23-30-fold) than the corresponding amount of IgA antibodies in serum. This generous quantity of colostral antibodies can be accounted for almost entirely by the higher total concentration (21-fold) of IgA in day 1 colostrum than in serum. Both the total amount of antibody and total $\operatorname{IgA}$ in colostrum fall abruptly after delivery so that by the 4th postpartum day their levels are similar to those in serum. In contrast to the sharp decline in total amount of $\operatorname{IgA}$ antibody per unit of colostrum during the first few postpartum days, the amount of antibody per milligram of breast fluid IgA remains nearly constant at about $0.5 \mu \mathrm{g} / \mathrm{mg}$. Uniformity in specific antibody content of colostral IgA during this short time might be expected because of secretion of preformed exocrine $11 \mathrm{~S} \operatorname{Ig} \mathrm{A}$. That values are similar, however, 6 weeks after delivery suggests that later in lactation the breast synthesizes or secretes IgA of a constant specific antibody level. Because we found that the concentrations of $\operatorname{IgA}$ antibodies and total IgA in breast fluids are parallel, the specificity of the radioimmunoassay is particularly critical. We believe that the test of specificity (Results) excluded any possibility that nonspecific adherence of $\operatorname{IgA}$ to bacteria was measured.

Concentrations of IgA in breast fluids in our study were comparable with those published previously (2). Others have reported a decline in the titers of $E$. coli agglutinins $(9,20)$ and $\operatorname{IgA}$ concentrations (2) in colostrum during the 1 st postpartum week.

Mechanisms by which breast milk antibodies are synthesized and secreted are largely unknown. Many authors (1, 25), partly because of inability to find serum antibodies corresponding to antibodies in colostrum, have doubted that serum antibodies are secreted by the breast. Results of this study indicate, however, that IgA antibodies to $B$. fragilis and $E$. coli are present in serum and therefore available for transfer into breast secretions. Nevertheless, we concur with others that the majority of breast milk antibodies probably are synthesized locally, because breast fluid and serum IgA antibodies are not quantitatively correlated in individual subjects, agglutinating antibodies are absent from the colostrum of parentally immunized rabbits while serum antibody activity is high (8), cells in colostrum synthesize secretory type $\operatorname{IgA}(21)$, and colostral IgA has an $11 \mathrm{~S}$ dimeric configuration whereas serum IgA principally is a $7 \mathrm{~S}$ monomer (25).

Bacteroides outnumber coliforms by about 1,000 times in the adult gut (4), but we found similar concentrations of antibodies to $B$. fragilis and $E$. coli in serum as well as in breast fluids. This finding is unexplained, but it may be evidence that $B$. fragilis evokes an antibody response less readily than $E$. coli or is less accessible to antibody-forming sites in the intestinal mucosa.

The biologic role of colostral IgA antibodies in regulating the gut microflora is unclear. Some have proposed that the lower number of coliforms in intestinal contents of breast-fed infants than in artificially fed infants is related to ingestion of antibodies to $E$. coli (20), although other factors might be equally or more important. The presence of antibodies to $B$. fragilis in breast fluids suggests that such antibodies could suppress the growth of Bacteroides in the neonatal gut and thereby account for the relatively low numbers of these anaerobic bacteria in stools of breast-fed infants (17). Because of the importance of Bacteroides in gastrointestinal physiology (11), the role of ingested antibodies to these and other indigenous anaerobes deserves further attention.

Results of this study indicate also that concentrations of serum antibacterial antibodies are not influenced by pregnancy or nursing. The levels of maternal IgA antibodies to $E$. coli and $B$. fragilis at delivery and 6 weeks later were similar, and levels in nursing mothers did not differ significantly from those in non-nursing mothers. Moreover, the antibody levels in these women were similar to those we have reported in males and nonpregnant, nonlactating females (3).

Both the levels of IgG and concentrations of $\operatorname{IgG}$ anti-E. coli antibodies (micrograms per milliliter of serum) were slightly higher in cord blood than in maternal serum, but the differences fell short of statistical significance, perhaps because 